\title{
The transformation of the temple in the Fourth Gospel
}

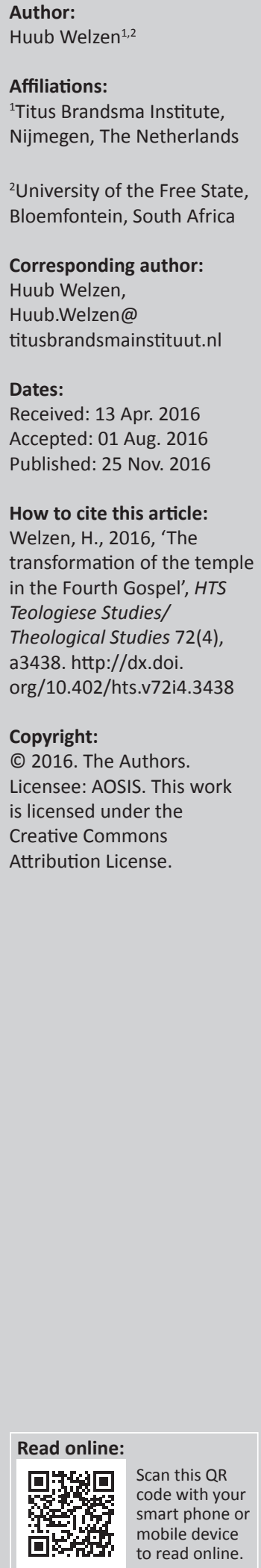

In at least two stories of the Fourth Gospel the transformation of the temple is an explicit theme. In the story of the cleansing of the temple the narrator comments that Jesus spoke of the temple of his body. In the dialogue with the Samaritan woman Jesus explains that God is no longer worshipped at mount Gerizzim or in Jerusalem, but in spirit and truth. In this article I will try to describe some aspects of this transformation against the background of the conflict between the Johannine congregation and the synagogue. As the dwelling place of God the temple is a holy place. Characteristic for the temple that Jesus is, is the mutual indwelling of God and Jesus and the mutual connection of Jesus and his disciples. The two mutual relations make it possible that the disciples come into contact with God. In the new temple that Jesus is, Jesus himself is the sacrifice of atonement. This atonement restores the relation of God and the believers. In the situation that is characterised by the absence of Jesus, the function of Jesus is taken over by the spirit of truth. That God is worshipped in spirit and truth makes a new inclusiveness and universality possible, where the conflict between the 'Jews' and Jesus' disciples is unsolvable because of the exclusive claims of the conflicting parties.

\section{Introduction}

\section{A situation of conflict}

Diamonds come into being under high pressure. From the viewpoint of spirituality and mysticism the Fourth Gospel belongs to the diamonds among the New Testament scriptures. This gospel wants to introduce its readers into the unity of God and Jesus, which is called the unity of Father and Son continually. Two articles by Jan van der Watt and Kobus Kok, (2008a, 2008b) discussing violence in this gospel of love, give an impression of the high pressure echoing in this gospel. They place the Fourth Gospel in a situation of conflict around the central question where the true God is to be located. In the gospel the conflicting groups are indicated as 'the Jews' and the disciples of Moses at the one side and at the other side the followers of Jesus. Their answers to the question where the true gods are to be located differ radically. The disciples of Moses think that the true presence of God can be experienced in the mosaic institutions of the Jewish religion such as covenant, law, prophets, temple, practices concerning purity, keeping commandments around feasts and Sabbath and so on. On the contrary the followers of Jesus think that God has revealed Himself in Jesus who has come to the world as Son of God out of love, to save the world. The Jewish externalisations of the presence of God such as temple, law, Sabbath and so on are taken up in the reality of Jesus' salvation and brought into another level. It is striking that van der Watt and Kok speak about a 'bargain' of the Jewish religion (2008a:1800).

The conflict is unsolvable. The reason is that both groups claim that God is on their side and that their religion is authentic. The exclusivity of their claims becomes clear by statements as in John 14:6: 'I am the way, and the truth and the life. No one comes to the Father except through me' ('̇ $\gamma \omega$ '

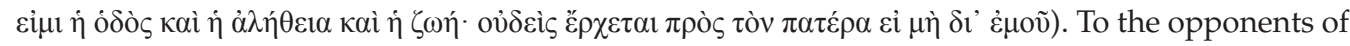
Jesus his claims that he is the revelation of God are unacceptable and blasphemous.

The controversy is presented in the book of John by disputations. Jesus justifies his claims. He defends them against the accusations of his opponents. This way of presenting is continuously present especially in chapters 5-10.

Jesus is at loggerheads with the Jewish leaders permanently, especially about his claim that He is the Son of God and as a consequence equal to God (5:16-18); He is going so far that he appropriates the name of God (8:58). This forensic background explains the frequent use of judicial concepts. (Ohuze 2001:1671)

Also words such as judging, accusing and the mention of the Holy Spirit as a lawyer ( $\pi \alpha \rho \alpha \dot{\alpha} \lambda \eta \tau$ ) $)$ play a role in such a forensic context. This has consequences for the readers of the Gospel. They 
come in the position of a jury that has to judge the argument. The difference with a jury in normal cases is that judgement of the readers is a religious conviction pro or contra Jesus. It has existential consequences for the readers.

According to many commentators the conflict is not only a controversy of the characters within the book, it is also a conflict in the situation in which the gospel has originated. It is supposed that in this situation a separation of the synagogue and the community of John has come about. The presence of the word $\dot{\alpha} \pi$ oбvvó $\gamma \omega \gamma$ os (been put out of the synagogue) (9:22; 12:42; 16:2; see also 9:35) is as an indication that this separation already has happened. In the conflicts of the Fourth Gospel the word oi 'Iovdaion (the Jews) appears frequently. Mary L. Coloe differentiates the use of this term. There is the neutral sense, which distinguishes the Jews from the Gentiles. The term is used in a positive sense too. In this positive use the word indicates the people of God in which the salvation work of God has started. Finally there is the negative use to indicate the people who take a stand against Jesus (Coloe 2001:88). The most important feature of this group is their hostility towards Jesus and his message from the beginning of the book (Kuhli 1981). Many proposals have been done for a more exact identification for this group: representatives of a world that is hostile to God; a group of Jews that abides by the law very strictly, inhabitants of Judea and representatives of the Jewish leaders. It is important to see that John has a more neutral use of the word, which distinguishes Jews and non-Jews (for instance 18:33, 35, 39; $19: 3,19,21)$. The polemic use of the word must not have been understood as an indication of the Jewish people as a whole. To avoid an anti-Semitic reading of the Fourth Gospel one has to realise that within the book of John Jesus and his followers consider themselves as Jews who participate in the salvation that God granted to his people. Significant for this is the utterance of Jesus in his dialogue with the Samaritan woman that salvation is from the Jews (4:22). The conflict in the book is an inner Jewish conflict. The same is true for the conflict of the synagogue and the Johannine community. It is a conflict of two Jewish groups which exclude each other. The conflict is about the question where and the manner how God can be met.

Against the background of this conflict within the book and the conflict in the situation where the Fourth Gospel came into being, I will try to describe the transformations of the opinions about the temple within the book. It is a radical change of the spiritual centre. Firstly I will say something about the temple as a holy place. After that I will throw some light on the transformation of the temple under three aspects: the temple as the dwelling place of God, the temple as the place where people sacrifice to God and the temple as the place where people worship God.

\section{The temple as a holy place}

The temple is a holy place. In the New Testament three word groups occur to indicate holiness. The first one is the group around the word ö $\gamma$ los. The second is around the word iєpóc.
The third group is around the word ö $\sigma$ os. The group around ärlos appears most frequently. In Hellenistic Greek ö $\gamma 10 \varsigma$ is not the common term for holy. It is iøpóc. That the Septuagint and the New Testament use most frequently words from the

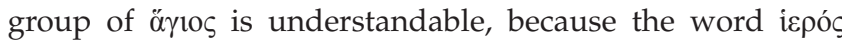
connotes pagan temples and all the things and persons that belong to these temples. The word ó $\gamma 10 \varsigma$ is related to the verb

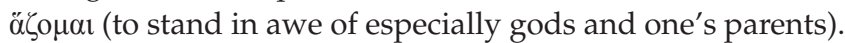
Originally the word has to do with God appearing in majesty. His appearance evokes fear and awe. In opposite to the Septuagint and the New Testament the word ó $\gamma 10 \varsigma$ is used relatively rarely in Hellenistic Greek. It is not used for the ethical and personal quality of persons. It only means the holiness of God that evokes respect, fear and awe.

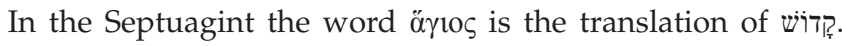
This word expresses the holiness of God as rooted in his power and perfection. It indicates a theological reality, transcendental to human reality. The word also indicates all the things, buildings, objects and persons that are related to this reality. Things dedicated to this transcendental reality are also called holy. In case the word is used to indicate persons not their ethical, moral and virtuous life, but their relationship to God is meant. It is because of its relationship

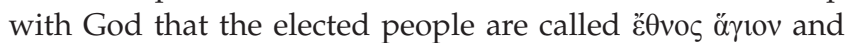
$\lambda \alpha$ ó $\alpha^{\prime} \gamma 10 \varsigma$. Nevertheless there is a relation of holiness to ethical, moral, virtuous and cultic life. Trespasses of religious, ethical, moral and cultic prescriptions have as a consequence that people do not belong anymore to the area of God. In this sense one can understand texts such as Leviticus 19:2; 20:7; 20:26; $21: 8$ and so on, where it is said: 'You shall be holy, for I the Lord, your God, am holy.' Perhaps the prescription of Matthew 5:48 (Be perfect, therefore, as your holy father is perfect) can be understood as an allusion to this kind of texts.

Many times the word ö $\gamma 10 \zeta$ appears in the system of cleanness and uncleanness. Classifications as cultic, ritual, religious, moral, ethical or hygienic are insufficient to understand the Biblical contrast of cleanness and uncleanness. For this contrast is a structure of the symbolic universe that organises the complete reality. Cleanness and holiness have to be understood as synonymous. In the religion of Israel the holiness of God is a dominant issue. Therefore, the system of cleanness and uncleanness is also a dominant element in the religion and society of Israel. Cleanness and uncleanness are the foundations for the rules in the areas of the cult, the religious and social life, hygiene, illness and health, death and sexuality. The most important issue is that uncleanness is the enemy of holiness. Uncleanness and holiness do not agree. Uncleanness is the consequence of the continuing attack on the holiness of God, the holiness of life, the holiness of the people of God and the society. It is the attack on God Himself. Holiness and uncleanness are of a great importance in relation to the cults in the temple. There are many prescripts to save the holiness of the temple and the cult. For uncleanness prohibits to be familiar with God.

The expression $\tau$ í iøpóv indicates the temple. The expression appears 70 times in the New Testament. It is used very 
frequently in Luke and Acts (in Luke 14 times; in Acts 25 times). Sometimes the total complex of the temple is meant, sometimes the specific building (Borse 1981a). The other word for temple in the New Testament is vaós. This is often the indication of the temple in Jerusalem (about 20 times). Paul and John use this word also in a metaphoric sense as an indication of the believer. In Revelation there is spoken about a temple in heaven. Normally ípóv indicates the temple complex as a whole, and voós the specific temple building. In pagan temples the statue of a god is erected in this building. But the God of Israel does not live in shrines made by human hands (Ac. 17:24). There is no statue of God in the temple of Jerusalem. It is said in Luke 1:9 that Zechariah enters the sanctuary and offers incense. In this sentence the Holy is meant and not the Holy of Holies. There are two curtains. The first one distinguishes the forecourts from the Holy, the second distinguishes the Holy of Holies from the Holy (Borse 1981b).

\section{The dwelling place of God}

The temple is the house where God dwells. The Hebrew word in connection with the names of gods is an indication for the dwelling place of the gods in question. When David had established his kingdom and has taken up his residence in a beautiful palace, he realised that the ark of God still stays in a tent (2 Sam. 7:2). He planned to build a house for God to live in. On several places in the Bible this plan of David is mentioned. A beautiful example is Psalm 132:3-5. David swore in this psalm:

I will not enter my house or get into my bed; I will not give sleep to my eyes or slumber to my eyelids, until I find a place for the Lord, a dwelling place for the Mighty One of Jacob. (Ps. 132:3-5)

Not David, but Solomon built the temple. At the moment the ark was brought to the Holy of Holies, Solomon says a long prayer (1 Ki. 8:23-53). In this prayer he reminds us that no temple can contain the Lord, and that the dwelling place of God is heaven. But he also remembers that the Lord has said: 'My name shall be there' (1 Ki. 8:29).

The story of the cleansing of the temple in the Gospel of John (Jn. 2:13-25) is not placed after the story of the entry into Jerusalem like in the synoptic gospels, but in chapter 2 after the story of the wedding at Cana. Besides John connects the cleansing of the temple with the word of Jesus that he will rebuild the temple in 3 days after its destruction. In the synoptic gospels this word is not said directly by Jesus. It is an utterance of the witnesses in the process of Jesus who declare that Jesus has said this word (Mt. 20:60; Mk. 14: 57-58). In the Fourth Gospel this word of Jesus gives occasion to a huge misunderstanding. Misunderstanding belongs to the literary design of the Gospel of John. In misunderstanding what Jesus says the occasion occurs to explain and to deepen this saying. The opponents of Jesus think that he speaks about the temple whose restoration Herod the Great began 46 years ago. But the narrator of the story remarks that Jesus spoke about the temple of his body. In this remark worlds change. The house of God is no longer the temple but the body of Jesus. The conflict we spoke about in the first section of this article becomes visible here. In my view it is not right to explain the action of Jesus from the fact that sheep and cattle were sold and money is changed in the temple. Mary M. Coloe says rightly that selling sacrificial animals and changing money in coins suited to pay the temple tax belong obviously to the normal business of a temple (Coloe 2001: 72-73). The saying of Jesus that the temple has become a marketplace is not an accusation against a degeneration of the selling of sacrificial animals and changing money, but it is a fundamental critic of the temple as such.

In the story three words are used as an indication of the

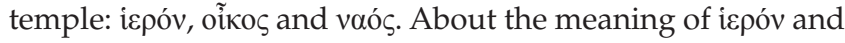
vaó $\varsigma$ we have spoken already. For the spiritual dimensions of the story it is important to see that the word oĩkos in verse 16

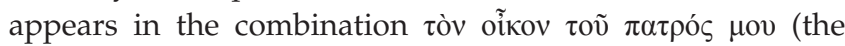
house of my Father). In this formulation the close alliance of Father and Son that is so characteristic for the Fourth Gospel becomes visible. Terms to indicate this alliance are among

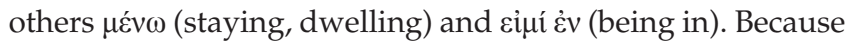
of the relation with the expression 'the house of my Father' we make a short exploration of the words $\mu \varepsilon \dot{v} \omega$ and eỉú $\dot{\varepsilon} v$ in the gospel of John.

Sometimes the word $\mu \varepsilon \dot{v} \omega$ has the meaning 'remaining some time in a place'. After the wedding at Cana Jesus went down to Capernaum with his mother, his brothers and his disciples,

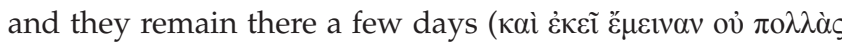
$\left.\dot{\eta} \mu \varepsilon \varepsilon_{\rho}\right)$ (2:12). After his conversation with the Samaritan woman some Samaritans asked him to stay with them, and he stayed there 2 days ('ท́์

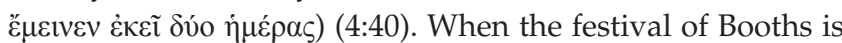
near and the brothers of Jesus go to Judea, they asked him to go with them. But Jesus answers that his hour has not come

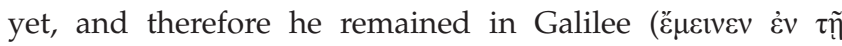
$\Gamma \alpha \lambda \imath \lambda \alpha i \alpha)(7: 9)$.

But Jesus stays also in other places than towns, villages and regions. His dwelling place is the love of his Father. Chapters 14 and 15 are illustrative of this. In these chapters Jesus says

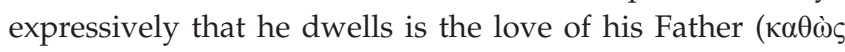

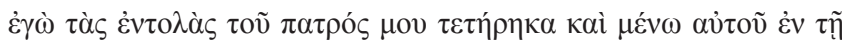
$\dot{\alpha} \gamma \alpha \dot{\pi} \eta\rceil)$ (15:10). But vice versa the Father dwells in Jesus. God works in Jesus by dwelling in Jesus:

Do you not believe that I am in the Father and the Father is in me? The words that I say to you I do not speak them of my own: but the

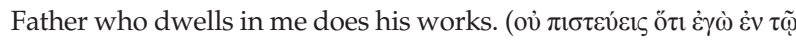

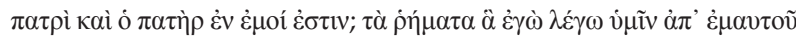

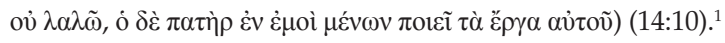

Jesus abides in God and God abides in Jesus. 'Believe me that

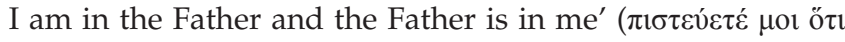

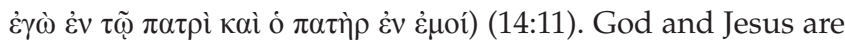
each other's mansions.

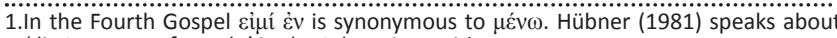
'die Immanenzformeln' in the Johannine writings. 
The mutual indwelling of God and Jesus in each other is not exclusive. The story of the disciples of John the Baptist who follow Jesus (1:35-39) has the depth that the disciples participate in the dwelling of Jesus in God. They ask: 'Where

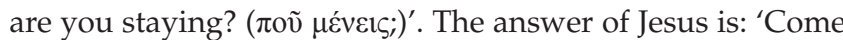

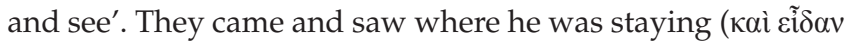

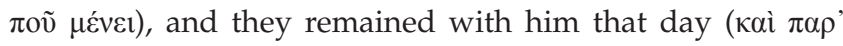

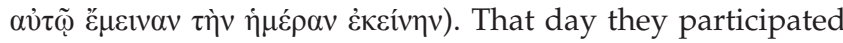
in the indwelling of Jesus in God.

The parable of the vine shows that there is an alliance of Jesus and his disciples. 'Abide in me as I abide in you. Just as the branch cannot bear fruit by itself unless it abides in the vine, neither can you unless you abide in me' (Jn. 15:4). The dwelling place of the disciples is the love of Jesus, in the same way as the dwelling place of Jesus is the love of God:

As the Father has loved me, so I have loved you: abide in my love. If you keep my commandments, you will abide in my love, just as I have kept my Father's commandments and abide in his love. (Jn. 15:9-10)

Here too there is a mutuality. 'Abide in me as I abide in you' (15:4). Jesus talks about the fact that the disciples abide in him and that his words abide in them (15:7).

Jesus has become the place where God dwells. There is also an association of Jesus and his disciples. Because of these two reasons the relation of the disciples with God becomes possible. This is the way Jesus neutralises the impossibility of the contact of human being with God, which is expressed in the first chapter of the Fourth Gospel. 'No one has ever seen God' (1:18). As a contrast with this impossibility Jesus says at the beginning of his farewell discourses that he makes possible the dwelling of the disciples in God. 'In the house of

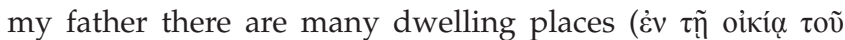

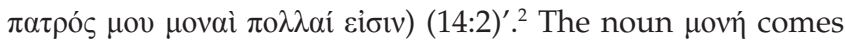
from the same root as the verb $\mu \varepsilon v^{\prime} \omega$. About his going to the Father Jesus says: 'If it were not so, would I have told you

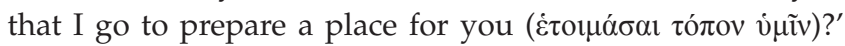
$(14: 2)$. The alliance of the disciples and God becomes possible by the work of Jesus.

For the readers of the book of John things are different. They struggle with the problem of the physical absence of Jesus. Their alliance with Jesus takes shape in a different way than the alliance of Jesus and his disciples. This is visible in the story of the cleansing of the temple too. The remembrance of the disciples is reported twice. In verse 17 the narrator tells that the

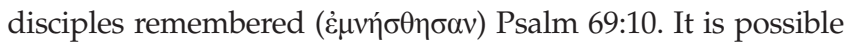
to understand the remembrance of the disciples as taking place at the exact same moment as the events told in the story. It is just necessary to presuppose that the disciples are present in this very moment and that they know what is happening; however, this is not told in the story. This is different in verses

2.In the opinion of Mary $L$ Coloe this statement is not about the believers coming to dwell in Gol's heavenly abode, but the Father, the Paraclede and Jesus coming dwell in God's heavenly abode, but the Father, the Paraclede and Jesus coming to dwell with the believers. "It is a "descending" movement from the divine realm to the human, not an "ascending" "movement from the human to the divine' (Coloe 2001:163). For me in this interpretation the context that Jesus goes to the Father is somewhat neglected.
21-22. First the narrator informs the reader that Jesus spoke about the temple of his body. After that he uncovers the misunderstanding of the Jews and Jesus. In verse 22 the narrator reports that the disciples remember that Jesus has spoken this word. He mentions the exact moment of this remembrance: after Jesus was raised from the dead (ö $\tau \varepsilon$ oũv

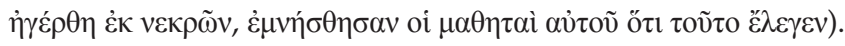
The time after the resurrection of Jesus is the time of the readers. The next word in this verse makes clear that in this moment the remembrance of the scripture and the word that Jesus has spoken brings the disciples to belief. This coming to belief conforms to the scope of the gospel as written in 20:30-31:

Now Jesus did many other signs in the presence of his disciples, which are not written in this book. But these are written so that you may come to believe that Jesus is the Messiah, the son of God, and that through believing you may have life in his name. (Jn. 20:30-31)

The remembrance of the disciples after the resurrection of Jesus helps in coming to belief, to establish the alliance with Jesus and via Jesus to restore the contact with God.

In the Fourth Gospel also, the authority is mentioned that wakes up the remembrance of the disciples. In the farewell discourses Jesus speaks about a paraclete that will come. The texts are very important for our purpose. In 14:16 Jesus says that God will send another paraclete at his intercession,

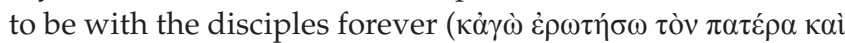

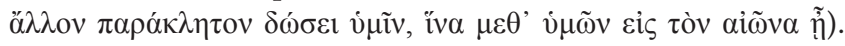
The expression 'another paraclete' which in verse 17 is identified with 'the Spirit of truth' indicates that the spirit the Father will send takes over the role of Jesus. ${ }^{3}$ John 14:26 is even more important. Jesus describes the task of the paraclete as teaching everything and reminding the disciples

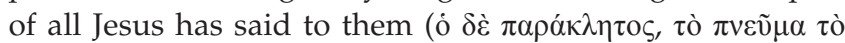

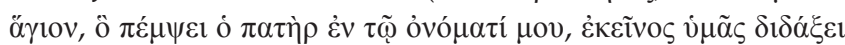

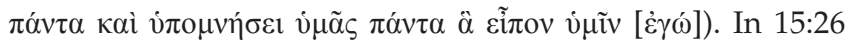
it is the task of the paraclete to testify on behalf of Jesus. In 16:7-11 Jesus underscores that it is necessary that he goes away, for if he does not go away, the paraclete will not come to the disciples. The forensic function of the paraclete is stressed in these verses. He will prove the world about sin, about righteousness and about judgement:

about sin, because they do not believe in me, about righteousness, because I am going to the Father and you will see me no longer, about judgement, because the ruler of this world has been condemned.

We can hear the polemic situation in which the Fourth Gospel originates, echoing in these texts. In which Bible book 16:13-15 the spirit of truth takes over the role of Jesus, for he will not speak on his own, but he will speak whatever he hears from the Father, just as Jesus did.

After the resurrection of Jesus the disciples will not be orphaned. The paraclete has the same function as Jesus. He will remind the disciples all Jesus has said. He allows it for the disciples to connect with God, just as Jesus did before.

3.'Dieser Bestand bzw. Helper wird die Rolle des irdischen Jesus nach seinem Weggang übernehmen; denn das "einen anderen" ist kaum zu überhören' (Schulz 1978:187). 


\section{The place of the sacrifices}

The temple is not only the holy dwelling place of God, it is also the place where people sacrifice. In this respect the quotation from Psalm 69:10 is important. Psalm 69 is a song of a servant of the Lord, who has to endure defamation and shame. He is accused of theft unjustly (Ps 69:3). His enemies threaten him. The reason for his suffering is his relation to God. He prays to God who has slain him that his enemies will be destroyed, and that God will rescue him from his misery. That will be a proof that God elaborates salvation. In the New Testament the psalm is related frequently with the suffering and death of Jesus (Jn. 2:17; 15:25; Mt. 27:34.48; Mk. 15:36; Lk. 23:36; Ac. 1:20) (Kraus 1961:485). In the story of the cleansing of the temple the Psalm is quoted after the Septuagint (Psalm 68:10 LXX). There is one difference.

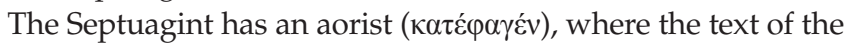

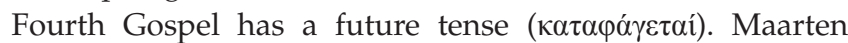
Menken investigated the function of the quotation in the context of the Fourth Gospel (Menken 1996:37-45). He mentions the view of many interpreters that Psalm 68:10 LXX is read by the author of the Fourth Gospel as a prophetic announcement of a future event that is realised in the cleansing of the temple. The zeal for the temple burns inside Jesus as an inner fire to such an extent that he drives the merchants who made the house of God into a house of trade, out of the temple. Menken remarks rightly that in such an interpretation the change of aorist in a future tense is not necessary. It seems to him that a better interpretation is that the future tense indicates the death of Jesus at the cross. In the psalm also the meaning of $\kappa \alpha \tau \dot{\varepsilon} \varphi \alpha \gamma \varepsilon \dot{v}$ is that the zeal for the house of God will bring to death:

The fact the zeal is 'consuming', does not signify in the psalm that the zeal totally dominates the psalmist, but that it brings him close to death. This meaning of Ps 69:10 makes it obvious that when reading the quotation in John 2:27, we should think of Jesus' death. (Menken 1996:41)

The fact that the remembrance of the disciples is mentioned twice and the second time it is explicitly told that this remembrance took place after Jesus was raised from death strengthens the idea that the quotation of Psalm 69:10 in John 2:27 relates the death of Jesus. It is the first time that in the Fourth Gospel the conflict of Jesus and 'the Jews' is mentioned. The quotation from the psalm shows how profound this conflict is and that it leads to the death of Jesus eventually. Sjef van Tilborg writes: 'The zeal for the house of his Father leads Jesus literally into death' (van Tilborg 1988:44).

Mary M. Coloe makes a further step. Exodus 30:11-16 plays a role in her interpretation. In this text it is provided that at the occasion of a registration of the Israelites a ransom for their lives shall be given, so that no plague may come upon them for being registered. Everybody has to pay half a shekel to the sanctuary to make atonement for their lives:

You shall take the atonement money from the Israelites and shall designate it before the service of the tent of meeting; before the Lord it will be a reminder to the Israelites of the ransom given for your lives. (Ex. 30:11-16)
According to Coloe this reminder is important. In the most cases when the Fourth Gospel uses the word remember, it bears a reference to the death and the resurrection of Jesus $(2: 22 ; 12: 16 ; 15: 20 ; 16: 4,21)$. The remembering of the disciples at verse 17 points ahead to the death of Jesus and to the gift of the Paraclete whose task it is to bring the disciples to remember (14:26). While Israel needed atonement sacrifices to bring them to remembrance, the community of believers will be brought to remembrance after the death and the resurrection of Jesus, through the guidance of the Paraclete (Coloe 2001:75). Coloe makes a connection with atonement sacrifices. Perhaps it is already in the quotation itself that the connection with sacrificial ceremonies is present. For the verb $\kappa \alpha \tau \varepsilon \sigma \theta i \omega$, of which $\kappa \alpha \tau \alpha \varphi \alpha ́ \gamma \varepsilon \tau \alpha i$ is the future tense, has also the meaning of consumed, in the way a sacrifice is consumed by fire (Bauer 1988:858-859).

The references to the death of Jesus and to the sacrificial ceremonies become very meaningful if these are related to the point of time that Jesus died in the Gospel of John. It is well known that the time table of the passion narration in the Fourth Gospel is not the same as in the synoptic gospels. It is true that the last supper is placed within the framework of the coming Passover (13:1), but the supper itself is not the celebration of Pesach. During the process of Jesus the 'Jews' do not enter the praetorium to avoid ritual defilement and to be able to eat the Passover (18:28). In 19:14 the narrator remarks that the critical moment in the process of Jesus is about noon on the day of preparation of the Passover ( $\tilde{\eta} v \delta \grave{\varepsilon}$

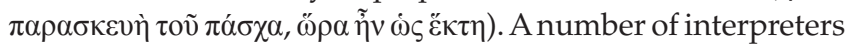
comment that Jesus dies at the same moment as the paschal lambs are slaughtered in the temple. In this way a new meaning of the slaughtering of paschal lamb comes into being. Jesus is the New Testament paschal lamb of which no bone has been broken (Schackenburg 1976:307). In 19:31 again is spoken about a day of preparation. Now it is a preparation day of Sabbath. The narrator tells that it was a great Sabbath. To make this remark in agreement with what is said in 19:14 one presupposes that Passover is on Sabbath in the timetable of the Fourth Gospel, while it is on Thursday in the synoptic gospel (Schackenburg 1976:336).

If the point of time that Jesus died coincides with the slaughtering of the paschal lambs in the temple, and if in this way Jesus becomes the new paschal lamb, also light is thrown on the statement of John the Baptist that Jesus is the Lamb of God who takes away the sin of the world $(1: 29,36)$. For this image of the Lamb of God different backgrounds are mentioned (Schackenburg 1972:285-288). People refer to the suffering servant in Isaiah 53. There are two points of contact. The first one is that the servant is compared with a lamb that is led to the slaughter, and a sheep that is silent before the shearers (Is. 53:7). The second one is that he has borne our sins (Is. 53:4 LXX). Sometimes it is underscored that carrying is not the same as taking away. The Septuagint uses the verb

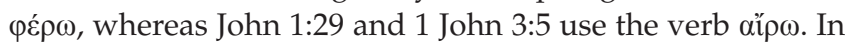
the text of John 1:19 the conciliatory character is important. In the verb $\varphi \varepsilon ́ \rho \omega$ this character is less clear as in the text of John. 
We already spoke about the reference to the paschal lamb. Also in 1 Corinthians 5:7 and 1 Peter 1:18-19 the idea of Jesus as the new paschal lamb is present. It is felt as an objection that the slaughtering of the paschal lamb in itself has no reconciliatory power. But Schnackenburg argues that a paschal theology is present in the Fourth Gospel (Schackenburg 1972:287). Sometimes interpreters refer to the daily sacrifice in the temple. In the morning as well as in the evening a 1-year-old lamb without any lack was sacrificed. In my view one must not exclude the possible reference to the scapegoat that was sent into the desert burdened with the sins of the people as a part of the ceremonies of the day of atonement (Lv. 16:10). This is not the same as in the case of the lamb that is mentioned in the book of Revelation. The context is completely different. In Revelation it is about a lamb that overcomes in the final struggle, while in the Fourth Gospel the accent is on the reconciliatory function.

To prefer one background with the exclusion of all the others seems to me not the right way to reach a good interpretation. I prefer the combination of the mentioned references as background for the reaching of a good meaning for the symbol of the Lamb of God: a symbol in which the community of John has expressed their experience with Jesus. For our description of Jesus as the new temple in the Fourth Gospel it is important that a number of the mentioned backgrounds are connected with the temple: the slaughtering of the paschal lambs, the daily sacrifice in the morning and in the evening, the ceremonies of the Day of Atonement. ${ }^{4}$

As a conclusion of this section we formulate that in the Fourth Gospel Jesus not only transforms the meaning of the temple, but also of the sacrifice. He himself is the sacrifice that restores the relation with God.

\section{The place where God is worshipped}

The temple is not only the dwelling place or the place where the sacrifices take place, but it is also the place where God is worshipped. This is an explicit subject in the dialogue of Jesus and the Samaritan woman (Jn. 4:4-45). Sandra Schneiders gives an analysis of this story reckoning with two levels of interpretation: the reality of the story within the book and the reality of the community of John. ${ }^{5}$ Her analysis throws light on the moment in the story that the question is discussed where the place of worshipping God is: on mount Gerizim or in Jerusalem. We follow the analysis of Sandra Schneiders as far as this is important for our purpose (Schneiders 2003:136-140).

A first element is that Sandra Schneiders considers the text as a missionary story. This becomes clear in the dialogue of Jesus and the disciples in verses 31-38 and the sayings of the Samaritans from the city in verses 39-42. In front of the

4.Jostein Âdna gives a comprehensive summary of the reconciliatory character of the cult in the temple (Ådna 200: 387-424).

5.The analysis of Sandra Schneiders is published as the final chapter of her book The Revelatory Text (Schneiders 1999:180-199). In this book the analysis functions as an example of her hermeneutic model for biblical spirituality. The analysis is also part of her book on the Fourth Gospel Written that you may belief (Schneiders 2003). disciples Jesus declares that his deepest hunger (namely to do the will of God) has been appeased by his conversation with the Samaritan woman and the things happening after it. He asks the attention of the disciples for the fact that Samaria is ripe for the harvest. He indicates that the conversion of Samaria is part of the missionary work of the Church. The disciples did not start this work and they are not able to do it. When the fellow citizens of the woman come, they do this because of the witness of the woman. They recognise Jesus as the saviour of the world. This is the expression used to indicate that the fellow citizens came to believe.

A second element is that Sandra Schneiders considers the woman as a representative figures or a symbolic character. Such a character represents a collective, without losing its particularity. Often such symbolic characters are nameless in the Fourth Gospel. Other examples of representative figures are the mother of Jesus, the beloved disciple, the royal official, the paralytic at the pool and the man born blind. The Samaritan woman is a symbolic character too. She is symbolic not only of the Samaritans who come to Jesus through the witness of the Johannine community, but she also symbolises the new Israel. This symbolic identity should warn against the sexual literalism to which many commentators immediately leap, whether in regard to the woman's supposed shady past or in regard to the woman's attempt to seduce Jesus.

According to Sandra Schneiders the discussion of Jesus and the Samaritan woman is religious and even theological from the very first moment. It is often suggested that she introduces theological issues as a smokescreen to distract Jesus from probing into her shameful sex life. The woman asks how Jesus, as a Jewish male, can ask a drink from a Samaritan woman. After the offering of living water by Jesus she asks if he is greater than their ancestor Jacob who gave the well to Israel. One of the characteristics of Samaritan theology is its mosaic-patriarchal foundation, as opposed to the Davidic-monarchical tradition of the Jews which concentrated in Jerusalem. For the woman the claim of Jesus to be on a par with Jacob has enormous theological implications.

Immediately after the exchange on the five husbands the woman recognises Jesus as a prophet (verse 19). She asks him where the true worship is to take place: on mount Gerizim as the Samaritans held or in Jerusalem as the Jews believed. According to the Samaritan theology the Messiah would not be a descendent of David, but a prophet as promised in Deuteronomy 18:18-19. He would restore true worship, not in the temple of Jerusalem, but in Israel, that is in the northern kingdom. The woman is pursuing a careful investigation of the identity of Jesus. She wants to know where Jesus stands on the issue of true worship, which in Samaritan theology is not only a prophetic concern, but specially a messianic one. Jesus transcends the Jewish and the Samaritan claims by saying that God is not worshipped on mount Gerizim or in the temple of Jerusalem but in spirit and truth. Because of this answer the woman thinks Jesus is 
the Messiah who would restore true Israel. Jesus confirms her intuition. He reveals himself to her not only as the

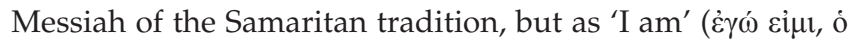
$\lambda \alpha \lambda \tilde{\omega} v \sigma o t)$ of the Mosaic tradition (Ex. 3:14) that is preferred in Samaria. It is the first time that the $\dot{\varepsilon} \gamma \omega \dot{c} \varepsilon \dot{\mu} \mu$ formula is used in the Fourth Gospel.

Within this religious and theological context it would be strange if the exchange about the five husbands is a reference to the sexual life of the woman. The woman has made a scrutiny to the points that are important for the Samaritan tradition. In the discussion with Jesus two points became clear. The first point is that the Samaritan claim to be a legitimate part of the chosen people and is recognised in the self-revelation of Jesus that he is a prophet like Moses was. The second point is that the controversy of Jews and Samaritans, of mount Gerizim and the temple in Jerusalem, has been overcome. Both traditions are challenged to give up their particular positions and to find their common identity in the revelation of Jesus as the truth. In this context the symbolic prophetic speech about adultery is used as a metaphor for idolatry. In 2 Kings 17:13-34 the religious situation of Samaria after the return of the remnants of the northern tribes from Assyrian captivity is pictured. It is about worshipping the idols of the five people who had been deported to Samaria by the Assyrians. The Jahwism of Samaria is coloured by idolatry. That is the reason that the text says that the husband the woman has now (a reference to the God of the covenant) is not her husband in the full sense of the word. This is also the reason that Jesus says that salvation is from the Jews. They worship what they know. Their belief in God is complete, but the Samaritans worship what they do not know. In saying that she has no husband the woman describes the religious situation of Samaria. Jesus affirms this by saying: 'What you have said, is true'.

The woman challenges Jesus' judgement by insisting: 'Our fathers worshipped on that mountain'. This means that the Samaritan tradition rests on the authority of the patriarchs. The answer of Jesus is that the question where God is worshipped has become irrelevant. When the Messiah has come, God is worshipped in spirit and truth. For God is spirit (verses 20-24). The woman is persuaded by this interpretation of the Samaritan tradition. She recognises Jesus as the Messiah. Jesus confirms her conclusion with a selfidentification as the Messiah and as the God of the Mosaic tradition 'I am' (verse 26).

According to this interpretation of Sandra Schneiders the situation of the Johannine community is mirrored in the dialogue of Jesus and the Samaritan women. A group of Samaritans participates in this community. In the dialogue of John 4 and also in the spirituality of the Johannine community both the temple in Jerusalem and the sanctuary in mount Gerizim are transformed. The oppositions between these two places where God is worshipped are overcome. God is no longer worshipped in one of these two places, but in spirit and truth. In this article we have already spoken about the spirit who makes possible the contact with God for the followers of Jesus in the situation of the absence of Jesus. If the function of the temple as the place of worshipping God does not exist anymore, and if this function now is fulfilled by Jesus, it is obvious that the spirit fulfils this function after the resurrection of Jesus. For the spirit is sent by the Father $(14,16)$ and by Jesus $(16: 7)$ to the disciples.

The place of worshipping God is spirit and truth. In this saying the spirit is connected with truth. We can see this connection in some other places in the Fourth Gospel. But it is always in a genitive construction: the spirit of truth (14:17; 15:26, 16:13). In the Fourth Gospel truth has to do with revelation (Hübner 1980). It is the truth of God that is revealed to the world by the incarnation of the Word (1:14; 1:17). Jesus speaks about the truth he has received from God (8:44, 45, 46; 16:7). Jesus not only testifies to the truth that God is. He is the revelation of God. This is the reason he can say: 'I am the way, and the truth, and the life' (14:6). John the Baptist has testified about this truth too (5:33). This truth will make free (8:32). The spirit of truth will bring the disciples into the truth of God. Jesus prays for his disciples that God sanctifies them in truth (17:17). This means that they become part of the world of God.

Just as Jesus reveals the truth of God to his disciples during his life and introduces into the truth, the spirit of truth will do this in the situation when Jesus is absent. That God is worshipped in spirit and truth mirrors the situation of the Christian community in which the spirit has taken over the function of the temple in the same way as Jesus did during his life.

Besides the story of the meeting of Jesus and the Samaritan woman clears up another important point. The religious and ethnic borders defined by holy places and holy traditions are broken down. The companionship of Jews and Samaritans, hindered by the worship of God that is restricted to a specific area, becomes possible by the worship of God in a new holy place, spirit and truth. This transformation of the temple makes a new universality possible. The exclusiveness of the claims which makes the conflict of the 'Jews' and the disciples of Jesus unsolvable is transformed to the inclusiveness and universality of the spirit of truth. In the new congregation the worship of God by several people and several beliefs are united.

\section{Conclusion}

As a conclusion we may indicate some points that are important for the Johannine interpretation of the holy place that the temple is. The temple in Jerusalem is not the dwelling place of God any more. The new holy place is the body of Jesus. It concerns a mutual indwelling. The son dwells in the Father and the Father dwells in the Son. There is a relation of the same art between Jesus and his disciples. Through the connection of Jesus, both with God and with his disciples, for the disciples the contact with God becomes possible.

Jesus is not only the new temple. He is also the sacrifice that is made in the temple. The expression 'lamb of God' used by 
John the Baptist to indicate Jesus has a wide spectrum of meanings. The timetable in the passion narrative gives a strong indication for a meaning of Jesus as the new paschal lamb. However, the paschal lamb in itself is not an expiatory sacrifice. But other associations of the expression indicate the expiatory power of the sacrifice. The sacrifice that Jesus is restores the relation with God.

For the readers of the gospel, who are confronted with the problem of the absence of Jesus, the spirit has become the temple of God. The spirit reveals the truth that God is. In respect of the readers of the Fourth Gospel the spirit has the same function as Jesus had in the book in respect to the disciples.

The background of these transformations of the temple is an inner Jewish conflict of the Johannine community and some Jewish groups. There is a rupture between the Johannine community and the synagogue. The conflict is unsolvable because of the claims of exclusivity of both parties. In the transformed temple where God is worshipped in spirit and truth, a new possibility for inclusiveness and universality comes into being. The worshipping of God is not restricted to a specific place.

\section{Acknowledgements Competing interests}

The author declares that he has no financial or personal relationships which may have inappropriately influenced him in writing this article.

\section{References}

Bauer, W., 1988, Wörterbuch zum Neuen Testament. 6., völlig neu bearbeitete Auflage von Kurt und Barbara Aland, de Gruyter, Berlin.

Borse, U., 1981a, ípóv. Exegetisches Wörterbuch zum Neuen Testament. Band II, Kohlhammer, Stuttgart, pp. 424-431.

Borse, U., 1981b, vaóc. Exegetisches Wörterbuch zum Neuen Testament. Band II, Kohlhammer, Stuttgart, pp. 1122-1126.

Coloe, M.L., 2001, God dwells with us. Temple Symbolisms in the Fourth Gospel, The Liturgical Press, Collegeville, MN.

Hübner, H., 1980, $\dot{\alpha} \lambda \eta \dot{\theta \varepsilon \imath \alpha}$. Exegetisches Wörterbuch zum Neuen Testament. Band I, Kohlhammer, Stuttgart, pp. 138-145.

Hübner, H., 1981, $\mu \varepsilon ́ v \omega$. Exegetisches Wörterbuch zum Neuen Testament. Band II, Kohlhammer, Stuttgart, pp. 1002-1004.

Kraus, H.J., 1961, Psalmen. 1. Teilband (2. durchgesehene Auflage), Neukirchener Verlag, Neukirchen.

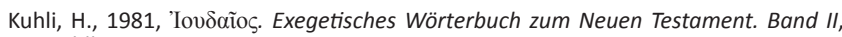
Kohlhammer, Stuttgart, pp. 1122-1126.

Menken, M., 1996, Old Testament quotations in the Fourth Gospel. Studies in textual form, Kok Pharos, Kampen.

Ohuze, T., 2001, Johannes. Internationaal commentaar op de Bijbel. Band 2, Kok/ Averbode, Kampen, pp. 1668-1731.

Schackenburg, R., 1972, Das Johannesevangelium. I. Teil. Einleitung und Kommentar zu Kap. 1-4. Dritte, ergänzte Aulage, Herder, Fraiburg.

Schackenburg, R., 1976, Das Johannesevangelium. III. Teil. Kommentar zu Kap. 13-21. Zweite, durchgesehene Auflage, Herder, Freiburg.

Schneiders, S.M., 1999, The revelatory text. Interpreting the New Testament as sacred scripture, 2 nd edn., The Liturgical Press, Collegeville, MN.

Schneiders, S.M., 2003, Written that you may belief. Encountering Jesus in the Fourth Gospel, New and expanded edition, The Crossroad Publishing Company, New York.

Schulz, S., 1978, Das Evangelium nach Johannes, Vandenhoeck \& Ruprecht, Göttingen.

Van der Watt, J. \& Kok, K., 2008a, 'Geweld in 'n evangelie van liefde: Die Evangelie van Johannes se perspektief op geweld tegen Jesus en sy discipels', HTS Teologiese Studies/Theological Studies 64(4), 1793-1812. http://dx.doi.org/10.4102/hts. v64i4.99

Van der Watt, J. \& Kok, K., 2008b, 'Jesus en sy discipels se reaksie op geweld in die Johannesevangelie', HTS Teologiese Studies/Theological Studies 64(4), 1813-1835. http://dx.doi.org/10.4102/hts.v64i4.98

Van Tilborg, S., 1988, Johannes, belichting van het Bijbelboek, KBS, Tabor. 